Jürgen von Hagen, an assistant professor of business economics and public policy at Indiana University, was a visiting scholar at the Federal Reserve Bank of St. Louis. Kevin L. Kliesen provided research assistance.

\title{
Monetary Targeting with Exchange Rate Constraints: The Bundesbank in the 1980s
}

$\mathbf{R}$ of economic policies have focused on the control of exchange rate movements among the major industrial countries. Such efforts gained visibility in the 1985 Plaza Agreement among the G5 nations (the United States, Canada, France, Germany and the United Kingdom) to curb the rising dollar, and in the subsequent joint efforts to prevent it from falling too low. ${ }^{1}$ Discussions of exchange rate coordination often neglect the potential conflict between exchange rate targets and domestic monetary policy objectives. Exchange rate policies may be costly, because a central bank may lose the ability to control domestic money growth and, hence, the domestic rate of inflation, in the effort to control exchange rates.

The purpose of this paper is to explore the impact of exchange rate policies on domestic monetary control during the 1980 s for one of the main players in the international arena, the German Bundesbank. The Bundesbank presents a particularly interesting case. On the one hand, it maintains a formal, explicit commitment to monetary targeting. On the other hand, it engages in exchange rate stabilization policies both inside the European Monetary System (EMS) and vis-a-vis the U.S. dollar. Recently, a number of authors have concluded that these joint commit. ments do not lead to significant conflict among the Bundesbank's policy objectives." Specifically, they argue that its participation in the EMS and in coordinated exchange rate policies in the G5 does not affect the Bundesbank's ability to achieve its monetary targets.

The analysis in this paper suggests that this conclusion is too optimistic for two reasons. First, it neglects important institutional aspects of the Bank's operating procedure; second, it neglects the fact that its exchange rate policies are geared to two different markets, the EMS and the dollar. When these aspects are taken into account, the evidence shows that German domestic money growth has been significantly affected by the Bundesbank's exchange rate policies in at least five years over the decade from 1979 to 1988.

TSee Funabashi (1988).

2Bofinger (1988), Camen (1986), Mastropasqua et al.

(1988), Obstfeld (1983), Rieke (1984), Roubini (1988). 


\section{MONETA GRRMAN}

Shortly after the 1973 breakdown of the Bretton Woods system of fixed exchange rates, which freed the Bundesbank from the obligation to intervene in the deutsche mark-U.S. dollar market to maintain the fixed dollar parity, the Bundesbank established monetary targeting as its monetary policy regime. A monetary target was first announced in late 1974. Monetary targeting has remained the basic policy regime in Germany, although, occasionally, changes have occurred in implementation procedures.

The Bundesbank announces annual monetary targets for a broad monetary aggregate. During 1975 to 1987 , the targeted aggregate was the "central bank money stock," a weighted M3 monetary aggregate, where M3 is the sum of currency in the non-bank sector, demand deposits and reserveable time and savings deposits. This aggregate is similar to the Federal Reserve's money stock definition for M2. In 1988, the Bank adopted the simple sum M3 as its target aggregate. Between 1979 and 1987, the targets were expressed as ranges of growth rates from the fourth quarter to the fourth quarter; only in 1989, the Bundesbank returned to its pre-1979 practice of announcing a precise fourth-quarter-to-fourth-quarter target growth rate.

\section{Reasons for Monetary Trageting}

Annual monetary targets impose limits on monetary policy activism and discretion. They imply that, over a year's time horizon, the central bank's actions have to be reconciled with its targeted growth rate of the money supply. The Bundesbank adopted monetary targeting to influence the public's expectations of future inflation and to provide the public with a standard of monetary policy that can be easily monitored to assess the credibility of the Bank's commitment to price stability. Targeting a monetary aggregate helps to reduce the economic cost of expectation errors about inflation that cause fluc-

3See e.g. Bundesbank, Monthly Report February 1975, Annual Report for 1975, Schlesinger $(1979,1983)$.

fFot a recent review of the European Monetary System, see Fratianni and von Hagen (1990). German iaw places the authority to participate in international exchange rate arrangements with the Ministry of Finance, not the tuations in output and employment, and allows the central bank to establish a reputation for commitment to price stability. This reputation helps to further reduce inflation expectations.

Monetary targeting also permits the Bundesbank to deny responsibility for labor and output market disequilibria, and to signal that monetary policy will not be available as an instru. ment of discretionary aggregate demand management. Both arguments arise from the basic view--laid down in the Bank's legal constitution-that the principal goal of German monetary policy is price stability. ${ }^{3}$

\section{Reasons for Exchange Rate Management}

Exchange rate management has been the second important determinant of Bundesbank monetary policy during the 1980s. Exchange rate considerations arise from two grounds. First, Germany's membership in the EMS obligates the Bundesbank to intervene in foreign exchange markets to maintain stable parities of the DM with the other participating currencies; these currencies are the French franc, the Belgian franc, the Dutch guilder, the Italian lira, the Irish punt, and the Danish korner. ${ }^{4}$ Under the EMS arrangement, member central banks are required to intervene without limits if necessary, to keep exchange rates within target zones of \pm 2.25 percent $( \pm 6$ percent for the lira) around predetermined central parities.

Second, the Bundesbank has often argued that intervention in the DM-dollar market is necessary at times to maintain "orderly" market conditions; that is, to dampen exchange rate fluctuations perceived to be unwarranted by the prevailing basic economic conditions or "fundamentals." While the Bundesbank has repeatedly denied having specific dollar targets for such interventions, the concept of unwarranted exchange rate movements implies that some fundamental value of the exchange rate is being considered and serves as a target for interventions.

Bundestank. One may, therefore, argue that the obligations implied by the EMS were imposed on the Bank. Indeed, the Bundesbank strongly opposed the formation of the EMS. 
Table 1

Monetary Targets and Exchange Rate Performance

\begin{tabular}{|c|c|c|c|c|}
\hline Year & $\begin{array}{l}\text { Monptrify target } \\
\text { (percent) }\end{array}$ & $\begin{array}{l}\text { healized } \\
\text { money growith } \\
\text { (percent) }\end{array}$ & $\begin{array}{l}\text { prative positi } \\
\text { h ne proy } \\
\text { agains uss }\end{array}$ & 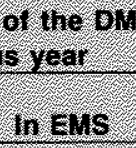 \\
\hline 1979 & 69 & 6.0 & 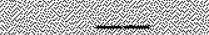 & - \\
\hline 1980 & 5.8 & 4.9 & nxed & $n \times d$ \\
\hline 1981 & 47 & 3.5 & weak & wedk \\
\hline $198 \%$ & 47 & 60 & weak & nured \\
\hline 1980 & 47 & 70 & weals & strong \\
\hline 1984 & 46 & 46 & Weak & newed \\
\hline 1985 & 35 & .5 & Weal & rirred \\
\hline 1986 & 655.5 & 77 & strong & sirong \\
\hline 1987 & 96 & 811 & strorig & strong \\
\hline 1988 & 36 & 67 & Shlong & strong \\
\hline
\end{tabular}

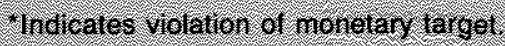

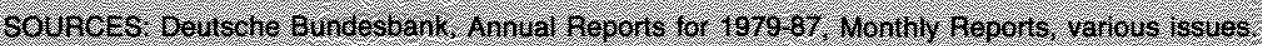

\section{The Relationship Retween}

\section{Monetary Control and Ezchange Rate Management}

The link between exchange rate policies and monetary control arises from the central bank's balance sheet. Domestic monetary control is achieved primarily by controlling the growth rate of the monetary base-total bank reserves plus currency in circulation-at an appropriate rate. The monetary base, from the sources' side, consists of various domestic assets and the central bank's stock of international reserves. Exchange rate control requires intervention in foreign exchange markets: purchases and sales of foreign assets which change the international reserves component of the base. Consequently, to assess the extent to which exchange rate policies affect domestic monetary control, one must answer the question of how much foreign exchange interventions affect the growth of the monetary base. This is called the "sterilization" issue. Only if foreign exchange interventions are "sterilized" completely, that is, have no effect on monetary base growth, will exchange rate policies not impede domestic monetary control. Otherwise, foreign exchange market interventions have some impact on the growth of the monetary base, and, consequently, on domestic monetary control. Sterilization of foreign ex. change market interventions requires offsetting sales or purchases of domestic assets, such that the total base remains unchanged.

\section{Monetray Trageting with Exchange

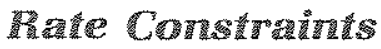

The monetary policy regime prevailing in Germany in the 1980 s can best be characterized as one of monetary targeting with EMS and U.S. dollar exchange rate constraints. Did these constraints prevent the Bundesbank from reaching its monetary targets? Table 1, which reports the monetary targets and realized growth rates in Germany since 1979 , provides a preliminary look at the answer to this question. During these years, the Bundesbank met its target on five occasions, and missed its target on five occasions. Money growth was too slow in 1980 and 1981, and too fast in 1986 to 1988 . The table also presents some qualitative information about the performance of the mark vis-a-vis the dollar and in the EMS during the previous years. Here, a "strong" position of the mark is typified by an appreciation of the mark and sales of DM reserves against foreign currency in the relevant market; the opposite is true for a "weak" position. A "mixed" position indicates that the mark switched between "strong" and "weak" during the year. 
Figure 1 illustrates these qualitative characterizations. The upper part of the figure shows an index of the DM-dollar exchange rate (red-line) and a weighted index of the DM exchange rates in the EMS (black-line). The lower part of figure 1 shows an index of the Bundesbank's net foreign asset position (red line) excluding net claims on the European Monetary Cooperation Fund (EMCF), and an index of its net claims on the EMCF (black line). Changes in these two foreign asset positions reflect the Bank's interventions in the dollar market and in EMS currencies, respectively. During 1980 and most of 1981, the dollar was rising and net foreign assets fell due to intervention supporting the mark. The mark's exchange rate in the EMS remained flat, but net claims on the EMCF fell, too. From 1982 to the end of 1984 , the dollar kept rising, while the mark appreciated steadily in the EMS. The two net foreign asset positions oscillated with little apparent trend. With the dollar's decline from early 1985 to the end of 1987 , a period of intervention to support the dollar began, reflected in the increase in net foreign assets during that period. As the mark remained strong in the EMS, net claims on the EMCF began to rise, too. Finally, in 1988, the mark was flat in the EMS, while the dollar was stronger again and the Bank heavily sold dollar assets.

Table 1 reveals a clear pattern in the connection of exchange rate performance and monetary targeting. There are four years, 1980, and 1985-87, when the mark's movements against both the dollar and the EMS currencies were in the same direction. Each of these years is followed by one in which the monetary target was violated, 1981 and 1986-88. Conversely, each year in which the mark's performance against the dollar was different from its perfor. mance in the EMS was followed by a year in which the monetary target was achieved. Since the mark's 1980 weakness against both already began in late 1979, the slight undershooting of the monetary target in 1980 fits into the same pattern. Note that the failures to meet monetary targets in each case were consistent in direction with the previous exchange market operations reflected in Figure 1: undershooting the targets in 1980 and 1981 followed a period of net sales of foreign assets, overshooting the targets in 1986-88 followed periods of net purchases of foreign assets by the Bundesbank.

Table 1 suggests that the pursuit of exchange rate objectives was associated with a failure to achieve the monetary targets in Germany. How* ever, the importance of the Bundesbank's exchange rate constraints seems to depend on whether the mark is moving in a similar or dissimilar direction in the dollar market and the EMS. Moreover, the link between the foreign exchange market operations and the growth rate of the money supply is not immediate; it involves time lags, although the lag is not necessarily as long as one year. The following section explains these qualifications in more detail.

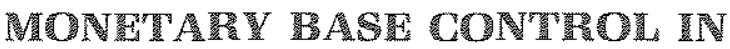

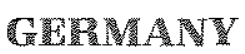

Equation 1 below describes the monetary base, B, by three net positions on the sources" side: assets in EMS currencies (IRE), dollar denominated assets (IRS), which, for simplicity, include gold, reserves in the International Monetary Fund (IMF) plus Special Drawing Rights (SDRs) and other foreign assets, and domestic assets (D). ${ }^{5}$

\section{(1) $B=\operatorname{IR} \$+\operatorname{IRE}+\mathrm{D}$}

A characteristic of the German financial system is that the domestic component consists almost entirely of Bundesbank loans to domestic commercial banks. In contrast to other major central banks, the Bundesbank's portfolio of open market paper-government securities and Treasury bills-makes up only a very small fraction of its assets. The structure of the sources of base money is illustrated by table 2 , which shows the base and the percentage shares of its main components for the period of 1978 to 1988. At the end of 1978 , international reserves

\footnotetext{
In practice, IRE consists of net claims of the Bundesbank against the European Monetary Cooperation Fund (EMCF), which pools reserves available for exchange market intervention in the EMS contributed by the participating cen* tral banks. Participating central banks can obtain strongcurrency reserves for obligatory interventions supporting their own currency from the EMCF, which leads to an increase in the net foreign asset position of the strong-
}

currency central bank. Conversely, if the latter intervenes to support the weak currency, it will transfer the acquired weak-currency reserves to the EMCF, again resulting in an increased net claim position. These rules of the EMS were designed to assure "symmetry" of interventions, i.e. that it does not matter which bank intervenes. 
Figure 1

Indexes of DM Exchange Rates and Bundesbank Net Foreign Assets

Monthly Data, April $1979=100$

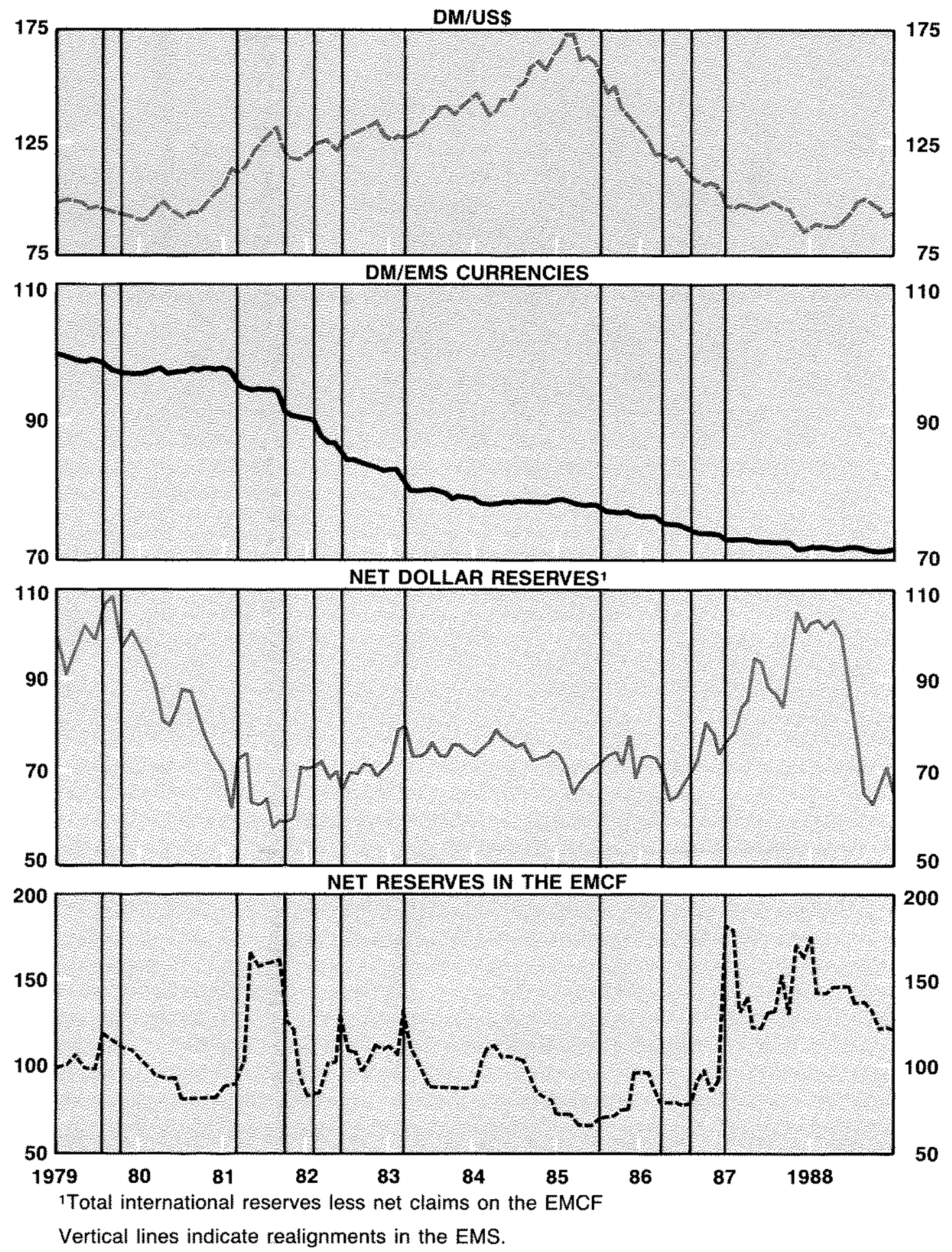




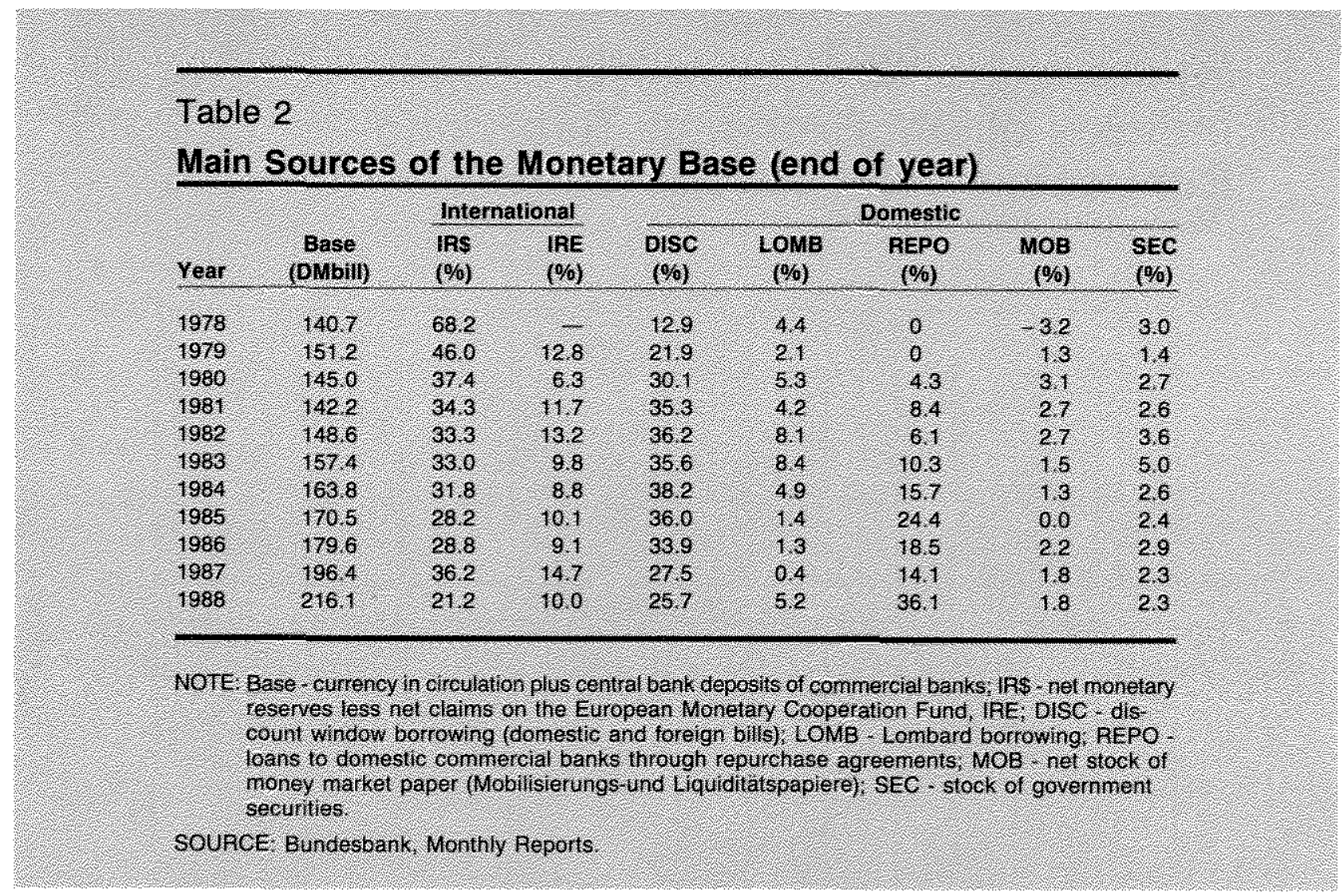

accounted for nearly two thirds of the base. That share declined to about 45 percent at the end of 1981. It climbed again from 38 to 51 percent during 1987 and fell sharply in 1988 .

Table 2 distinguishes the three most impor. tant types of loan operations in the domestic component: discount credit (DISC), Lombard credit (LOMB) and repurchase agreements (REPOs). In Germany, discount credit is rationed and the discount rate is kept consistently below money market rates, and commercial banks have additional incentives to fully utilize their discount quota. ${ }^{6}$ Consequently the Bundesbank can tightly control the quantity of discount credit. Discount credit is collateralized with trade bills and has a fixed maturity of up to 90 days.

Lombard credit, in contrast, is freely accessible to banks under normal circumstances at a

6For example, an individual bank's quota may be reduced if it has not been exhausted for some time. This practice implies that variations in the discount rate have no direct impact on the money supply. The important variable determining the quantity of discount credit is the tolal size of discount quota. rate that is kept higher than money market rates. The Bundesbank may, however, impose quantitative restrictions on Lombard credit also. Lombard credit, which is collateralized with trade bills, securities and Treasury bills and can be repaid at any time, is a more flexible refinancing instrument than discount credit for commercial banks.

Repurchase agreements are loans to commer. cial banks collateralized with securities, tradebills or foreign assets. ${ }^{7}$ Typically, they have fixed maturities between three and 30 days and are available only at the Bundesbank's discretion. The table shows that REPOs gained importance during the 1980s.

The two remaining components of the domestic sources of the German monetary base shown in table 2 are the Bundesbank's stock of open market paper, securities issued by the Fed. eral or State Governments, the Federal Railroad

The official terms for these operations, "open market operations with repurchase agreements," is misleading in that their economic nature is a loan to a commercial bank, using a bank's asset as collateral. That is, the Bundesbank does not purchase or sell securities or trade bills in these operations. See Bundesbank (1985). 
or the Federal Post Office (SEC), and the net Treasury bill position (MOB). ${ }^{8}$ The Bank can issue Treasury bills, "Mobilisierungs-undLiquiditätspapiere" on its own initiative, but only up to the amount of DM 16.5 billion. During the period under consideration, the combined share of MOB and SEC never exceeded 7 percent of the base.

An important consequence of the Bundesbank's asset structure is that the domestic component, $\mathrm{D}$, is controlled mainly via loans to domestic banks. For this purpose, the Bundesbank has developed a two-stage strategy. ${ }^{9}$ It is based on the decomposition of the domestic component into a permanent part $(\mathrm{P})$ and a transitory part (T):

(2) $\mathrm{D} \equiv \mathrm{P}+\mathrm{T}$.

The permanent part $(\mathrm{P})$ is used to achieve the desired trend growth of the domestic component over a time horizon of several months. The main policy instruments for its control are purchases and sales of securities (SEC), reserve requirements, the discount rate and discount quota. ${ }^{10}$

The transitory component (T) is used to control the short-term growth of the monetary base with regard to current money market conditions. Here, the main policy instruments are the issue and redemption of Treasury bills (MOB), repurchase agreements, including loans collateralized with foreign assets (REPO) and Lombard credit (LOMB). ${ }^{11}$

Variations in $T$ are geared primarily at reducing short-run fluctuations in the interbank rate for overnight central bank funds, the Bundesbank's principal operating target for monetary control. ${ }^{13}$ The Bundesbank stresses the shortrun character of these operations by calling them "reversible money market operations." Reversible money market operations have typical maturities between two and thirty days;

8MOB is the difference between "Equalization Claims" on the Federal Government and "Llabilities to Banks from issuing Mobilization and Liquidity Paper" in the Bundesbank balance sheet.

9For detailed discussions, see Dudler (1988), Neumann (1988).

10Note that SEC and discount credit policies operate on the supply side of base money; reserve requirements impact on its demand.

Hoans collateralized with foreign assets, foreign exchange swaps-the combination of a foreign exchange operation only recently has the Bundesbank introduced repurchase agreements that extend over two months. Under the current two-stage strategy, increases or decreases of the transitory component are generally reversed after some time. That is, they are neither intended nor permitted to have a lasting impact on the total domestic component or on the base. The notable exception to this policy design was the increase in REPO during 1984/85, when the Bundesbank decided to increase the stock of REPO to gain more flexibility in its use to control money market conditions. ${ }^{13}$

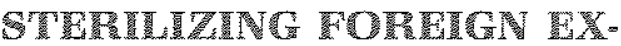

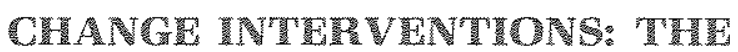 CABE OF TIE BUNDESPAN}

In view of equations 1 and 2 , we can now write the change in the monetary base during a period $t$ as:

(3) $\Delta \mathrm{B}_{\mathrm{t}}=\Delta \mathrm{IR}_{\mathrm{t}}+\Delta \mathrm{P}_{\mathrm{t}}+\Delta \mathrm{T}_{\mathrm{t}}$,

where $\Delta \operatorname{IR}_{t}\left(=\Delta \mathrm{IR}_{\mathrm{t}}+\Delta \mathrm{IRE}_{\mathrm{t}}\right)$ is the change in the total international reserves component. Consider now the impact of an exchange market intervention, say, to support the dollar. This requires an increase in foreign assets, $\Delta \mathrm{IR}_{\mathrm{t}}>0$. Under the two-stage control procedure described above, the Bundesbank may simultaneously reduce the transitory component if it wants to neutralize the immediate effect of the intervention on the monetary base. Thus, we may assume:

(4) $\Delta \mathrm{T}_{\mathrm{i}}=\zeta \Delta \mathrm{IR}_{1}+v_{3}$

where $v_{t}$ is a random variable that represents all other changes in the transitory component. Inserting (4) into (3) yields:

(5) $\Delta \mathrm{B}_{\mathrm{t}}=(1+\xi) \Delta \mathrm{IR}_{\mathrm{t}}+\Delta \mathrm{P}_{\mathrm{i}}+V_{\mathrm{i}}$.

in the spot market with the opposite operation in the for ward market-and "deposit policy" - temporary transfers of central bank deposits of the Federal Government into and out of the banking sector-are additional, but less important, components of $\mathrm{T}$. Loans collateralized with foreign assets and toreign exchange swaps do not change the Bundesbank's net foreign asset position. See Bundesbank (1985).

12See von Hagen (1988).

13See Bundesbank, Monthly Report, October 1985. 
If $\zeta=-1$, the intervention is fully sterilized in the current period: There is no current effect on the base.

The two-stage monetary control strategy implies, however, that things do not end here. The initial decrease in the transitory component is reversed during subsequent periods. As this happens, the effect of the initial intervention on the growth of the monetary base is gradually realized. Therefore, even if foreign exchange interventions are sterilized completely in the cur. rent period, the growth of the base need not be independent of foreign exchange interventions in the longer run. Independence of base growth from foreign exchange interventions in the longer run can only be achieved by counteracting their effects with appropriate changes in the permanent component.

As a consequence of its control strategy for the monetary base, the Bundesbank has developed a two-stage sterilization procedure. ${ }^{14}$ The essential point is to distinguish between shortrun and long-run sterilization. The former is brought about by variations of the transitory component as discussed above; the latter requires changes in the permanent component. To illustrate the two-stage procedure, let the change in the permanent component be:

(6) $\Delta P_{t}=u_{t}+\sum_{j=1}^{m} \delta_{j} \Delta \mathrm{IR}_{\mathrm{t}-\mathrm{j}}$

where $u_{i}$ denotes changes in the permanent component, independent of exchange rate policies. Here, the sum $\sum_{j=1}^{m} \delta_{j}$ determines the degree of sterilization in the long run, and the individual $\delta_{j}$ parameters show how the steriliza tion with the permanent component is distributed over time. The effect of a one-time intervention in period $t$ on base money growth in the current period can be represented as:

(7) $B_{t}-B_{t-1}=u_{t}+(1+\xi) \Delta I R_{t}+v_{t}$

while the long-run effect is apparent from:

(8) $B_{t+m}-B_{t-3}=\sum_{j=0}^{m}\left(u_{t+j}+v_{t+j}\right)+\left(1+\sum_{j=1}^{m} \delta_{j}\right) \Delta \mathrm{IR}_{t}$.

Equations (7) and (8) highlight the different roles of short-run and long-run sterilization in influencing the growth of the monetary base. Short-run sterilization reduces the immediate impact of an intervention on the monetary base and serves to distribute its effect more smoothly over time. Only long-run sterilization, however, can make monetary base growth independent of the consequences of exchange rate policies. This requires $\sum_{j=1}^{m} \delta_{j}=-1$, and is independent of the degree of short-run sterilization. For the conflict between monetary targeting and exchange rate targeting, the degree of long-run sterilization is the relevant issue because it determines the consequences of exchange market interventions on money growth over time.

Two conclusions can be drawn at this point. First, the strong negative correlations between contemporaneous or short-lagged changes in the domestic component and the international reserves component of the base pointed out by Camen (1986), Obstfeld (1983), Roubini (1988), Mastropasqua et al. (1988) and Bofinger (1988) only tell us about a high degree of short-run sterilization. Given the control strategy of the Bundesbank, these results per se have no im. plications for the independence of the Bundesbank's domestic monetary policy goals from its exchange rate policies in the EMS of in the coordination efforts of the G5.

Second, even if the degree of short-run sterilization is high, foreign exchange interventions can produce accelerations or decelerations in base and money over time simply because changes in the transitory component are reversed only gradually and with a lag of several periods. Therefore, the lag pattern found in table 1 is consistent with this distinction between short-run and long-run sterilization.

\section{Of seturg Interventions}

In practice interventions may not seriously endanger monetary control even if they are not sterilized in the long run. For example, different interventions can offset each other and thus neutralize their individual effects on monetary base growth. Such "offsetting" interventions can occur either over time or across markets.

Offsetting interventions that occur over time are possible if, in the absence of interventions, the exchange rate is subject to purely transitory, random fluctuations of mean zero, while the underlying "fundamental" exchange rate is constant. If the central bank decides to dampen exchange rate movements by intervening in the

14See Dudler (1988). 
foreign exchange market, the resulting interventions would produce purely transitory fluctuations in the international reserves component. Since these fluctuations average out to zero over time, they contribute nothing to the growth of the monetary base over time, even without sterilization. ${ }^{15}$

Unfortunately, the fundamental exchange rate is not constant, as illustrated by the large swings in the DM-dollar rate and the persistent appreciation of the mark in the EMS since 1981 shown in figure 1 . Worse than that, the fundamental rate is not known. Therefore, every change in the exchange rate can represent a fundamental change, a transitory change, or the sum of both. Thus, interventions to smooth only transitory fluctuations require knowledge of what is transitory and what is not, knowledge which is not available to policymakers. Misinterpreting fundamental for transitory movements will lead to interventions that do not average out over time, and therefore cannot be sterilized by the transitory base component alone. ${ }^{16}$

The dual exchange rate constraints in the EMS and the dollar market create an opportunity for the second kind of offsetting interventions. This could occur if, for example, intervention in the EMS is required to bring the mark's value in other EMS currencies down, while the mark is weak against the dollar at the same time. Intervention in the EMS then requires purchases of reserves, $\triangle \mathrm{IRE}>0$, while stabiliz. ing the mark against the dollar requires sales of dollar assets, $\Delta I R \$<0$. Such offsetting operations across the two markets seem to have occurred frequently between 1982 and 1985 . For example, the Bundesbank reports that "the considerable inflows of foreign exchange from the EMS area did not pose any problem for Germany on balance because the Bundesbank simultaneously sold heavily in the dollar market in the form of smoothing interventions in favor of the Deutsche Mark." 17 In the figure, this is most clearly visible during 1982 . Since the monetary base is affected only by the net change of the total international reserves component, the sterilization problem is considerably alleviated in this situation.

Thus, with two exchange rate constraints, the consequences of exchange rate policies for monetary targeting depend on the relative movement of the mark in the two markets. Specifically, the Bundesbank's exchange rate constraints are more likely to jeopardize monetary control if the mark is moving in the same direction in both markets, because this limits the possibility of offsetting interventions across markets. This suggests that empirical studies of the degree of sterilization by the Bundesbank should distinguish between periods of equal or opposite movements of the mark against the dollar and the EMS.

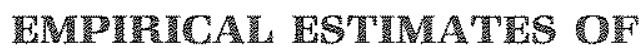 SHOTR'TUN STP}

In this section I estimate the degree of sterilization of foreign exchange interventions for the Bundesbank over the period of 1979-88. In contrast to earlier studies, I distinguish between short- and long-run sterilization and look at subperiods according to the mark's relative strength.

\section{The Date}

The analysis is based on monthly data for changes in the monetary base and its sources from the Bundesbank's Monthly Reports. The data are calculated from averages of daily figures and are not seasonally adjusted. Changes in the international reserves component, $\Delta I R$, are measured as "foreign exchange inflows to or outflows from the Bundesbank." These foreign exchange flows are reported in actual, effective transaction values and measure precisely their effect on the base. This is the

\footnotetext{
15They do, however, increase the variability of base growth. Statements by the Bundesbank indicate that this is indeed its paradigm for exchange rate policies with regard to the dollar: Interventions are geared to dampen "erratic" Huctuations of the DM-dollar rate around the fundamental rate. See e.g. Dudler (1988), p. 69, Scholl (1983), p. 120.

16The Bundesbank has admitted that such interpretation errors have led to undesirable monetary developments on numerous occasions. See Bundesbank, "Vierzig Jahre Deutsche Mark," Monthly Report, May 1988.
}

17Annual Report for 1981, p. 76; see also Annual Report for 1982, p. 72, Scholl (1983), p. 124. 
main advantage of using these data rather than balance sheet data, where, in accordance with German accounting laws, international reserves are reported at constant exchange rates throughout each year. ${ }^{18}$ One problem arising with these data-as well as with balance sheet data-is that they do not distinguish between changes in international reserves due to intervention and changes due to other sources. Even without intervention, the net foreign asset position of the Bundesbank would change over time as interest income on foreign assets is collected and exchanges of DM for dollars takes place in regular business with U.S. armed forces stationed in Germany. ${ }^{19}$ However, in the present context of testing for short-run and long-run sterilization, this does not pose a serious problem. ${ }^{20}$

For interventions in EMS currencies, balance sheet data must be used. IRE is measured by the Bundesbank's net claims on the EMCF in connection with the EMS. Dollar market interventions are then obtained from $\triangle I R$ - $\triangle I R E$ $=\Delta$ IR $\$$. Finally, to obtain an empirical counterpart of the transitory base component (T), we use the bank's "balance of short-term assistance measures on the money market" and add Lombard loans outstanding. ${ }^{21}$ The monthly changes in these variables are normalized by the lagged monetary base to obtain scale-free variables.

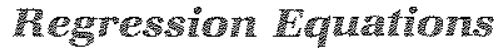

I estimate the following regression model for the transitory component:

$$
\begin{aligned}
& \text { (9) } \Delta T_{t}=\pi_{1}+\sum_{j=1}^{k} \alpha_{1, j} \Delta T_{t-j}+\alpha_{1,12} \Delta T_{t-13} \\
& \sum_{j=1}^{n} \beta_{1, j} \Delta \operatorname{IR} \$_{t+1-j}+\sum_{j=1}^{m} \gamma_{1 ; j} \Delta I R E_{i+1-j}+v_{t}
\end{aligned}
$$

The model has an autoregressive part and two sets of regressors, the two intervention variables $\triangle I R \$$ and $\triangle I R E$. In equation 9, the parameter sums $\sum_{j=1}^{n} \beta_{i, j}$ and $\sum_{j=1}^{m} \gamma_{1, j}$ estimate the total degree of short-run sterilization achieved with the transitory component, while the individual coefficients $\beta_{1, j}$ and $\gamma_{1, j}$, show how this is distributed over the current and the following months.

The model for the monetary base is:

$(10) \Delta \mathrm{B}_{\mathrm{t}}=\pi_{z}+\sum_{j=1}^{\mathrm{K}} \alpha_{2, j} \Delta \mathrm{B}_{\mathrm{t}-\mathrm{j}}+\alpha_{2,12} \Delta \mathrm{B}_{\mathrm{t}-12}+$
$\sum_{j=1}^{\mathrm{N}} \beta_{2, j} \Delta \mathrm{IR} \$_{\mathrm{t}-\mathrm{j}}+\sum_{\mathrm{j}=1}^{\mathrm{M}} \gamma_{2, j} \Delta \mathrm{IRE}_{\mathrm{i}-\mathrm{j}}+\mathrm{w}_{\mathrm{i}}$

Here, the sums of parameters $\sum_{j=1}^{N} \beta_{2, j}$ and $\sum_{j=1}^{M} \gamma_{2,1}$ measure the total impact of a given intervention on the base; $\beta_{2, j}$ and $\gamma_{2, j}$ reflect its distribution over time.

I estimate equations (9) and (10) over the total period, 1979 to 1988 , and three subperiods. ${ }^{22}$ These subperiods, while necessarily somewhat arbitrary, were chosen in accordance with the characterizations shown in table 1: 1980-81 was a period in which the mark was generally weak against both the dollar and the EMS currencies, 1985-87 was a period in which the mark was mostly strong against both currency groups; 1982 to 1984 was a period in which the mark was generally weak against the dollar and strong against the EMS currencies.

Preliminary estimates of the two equations were run to select the appropriate lag lengths for the regressors. The preferred specifications have $k=K=3$ lags for the autoregressive part
18See Roubini (1988) for a discussion of valuation problems with balance sheet data.

19 See e.g. Monthly Report, November 1988, p. 32.

2oWe may interpret $\Delta I R$ as the sum of the true effect of interventions plus a measurement error from other changes in international reserves. It is well-known that such errorsin-variables bias regression coefficients toward zero, unless the covariance of the measurenent error and the equation error is positive and large relative to the magnitude of the coefficient being estimated. In tests of a shortrun sterilization coefficient of negative one, and of no longrun effect of $\triangle \mathrm{IR}$ on the base, the test is biased against full short-run and in favor of full long-run sterilization. Since the test results accept the former and reject the latter, they are actually stronger than indicated by the nominal significance levels used.

21All data except IRE are obtained from the Bundesbank's table III.3. IFE is taken from the Bank's table IX.6a.
22We estimate equations 6 and 8 together with an auxiliary equation for total interventions, AIR, or dollar market interventions, $\Delta \mathrm{IR} \$$, using a three-stage least-squares (3SLS) estimator. The equation for $\triangle \mathrm{AR} \$$ is a regression of these interventions on a set of instruments, namely lagged interventions, lagged changes in the DM-dollar rate and lagged German-U.S. interest rate differentials for call money and government securities. The use of these instruments allows us to solve the simultaneity problem that arises in equations 7 and 9 , as exchange rates and hence interventions may be contemporaneously affected by changes in the base. Furthermore, the use of the 3SLS estimator is appropriate to account for the likely correlation of the error terms $u_{1}$ and $w_{1}$. For the EMS interventions, an instrumental estimator was not used because there were no appropriate instruments. 


\section{Table 3}

\section{Results for Transitory Sterilization (dependent variable AT)}

\begin{tabular}{|c|c|c|c|c|c|c|c|c|c|c|}
\hline \multirow{3}{*}{ Sample } & \multirow{2}{*}{\multicolumn{2}{|c|}{ own lags }} & \multicolumn{4}{|c|}{ uninary of Esti } & \multirow{3}{*}{$S E(\%)$} & & \multirow{3}{*}{ R } & \multirow{3}{*}{$\mathbf{A R}(6)$} \\
\hline & & & & & & & & & & \\
\hline & & $20 \%$ & 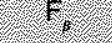 & & Fi & $2 \sqrt{2}, 3$ & & & & \\
\hline (0. -12188 & 4.3. & -0.21 & $121 \times$ & $=0.74$ & $109=$ & -0.882 & 2.70 & $46.0^{* *}$ & 0.54 & \\
\hline & $6.0 \%$ & -133 & 6. 11: & -1.17 & 89 & $=167$ & 4.7. & $4.0^{\prime *}$ & 8 & \\
\hline & $28^{*}$ & 032 & $10.4^{t}$ & $=1.25$ & $62 \%$ & -1 & 285 & $6 *$ & 2 & \\
\hline & $4.6 \%$ & $-0.3 x$ & $11.4=$ & $=0.80$ & $6.5 \%$ & 0.36 & 272 & $7.8 *$ & 0.70 & \\
\hline
\end{tabular}

Tests tor Shoit Run Sterilization (cegrees or treedom in parentieses)

\begin{tabular}{|c|c|c|c|}
\hline 179.1268 & $(2,325)$ & $(0,0)$ & $\left(\begin{array}{l}1 \\
(2.325)\end{array}\right.$ \\
\hline $60 / 1218$ & $(1,8)$ & $\left(\begin{array}{l}3.6 \\
(10)\end{array}\right.$ & $(2,9,40)$ \\
\hline 82,12184 & $(0.6)$ & $(1,76)$ & 0.8 \\
\hline 85.1287 & $(0.6)$ & $\left(\frac{5}{(1,7)}\right.$ & $(26)$ \\
\hline
\end{tabular}

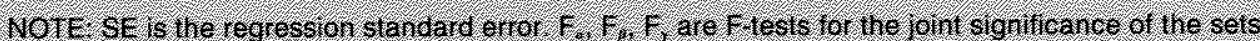

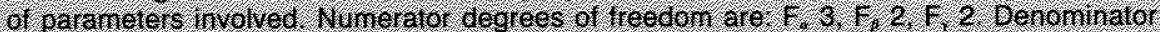

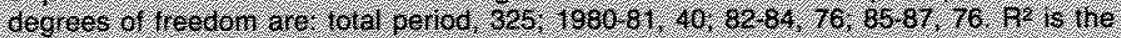

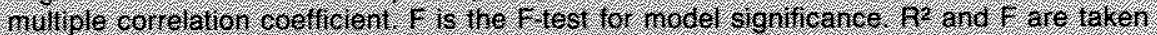

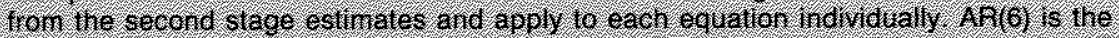

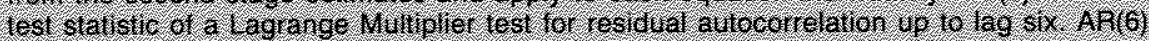

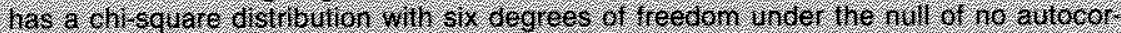

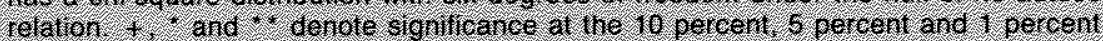
16.615 .

and $m=n=1$ lag for the intervention variables in the transitory component model, and $N=6$ and $M=4$ lags for dollar and EMS inter. ventions in the base equation. These specifications were chosen because the inclusion of more lags did not improve the model's explanatory power, while further restrictions reduced it.

\section{Short-Run Sterilization}

Table 3 summarizes the result for the transitory component equation. The upper panel indicates that the regressions are highly significant for all samples and explain monthly changes in the transitory component fairly well. The AR(6) statistic shows no signs of residual autocorrelation. The significant negative sum of the AR coefficients agrees with the reversibility of the short-run operations involved. The only exception in the subsample 1982-84 where the own lags are not significant, presumably reflects the Bundesbank's attempt to build up a larger portfolio of loans to banks with repurchase agreements during this period. Both sets of intervention variables appear highly significant. In all subsamples and the total sample, the sums of the short-run sterilization coefficients $\beta_{1, j}$ and $\gamma_{1, j}$ have the expected negative signs.

Based on equation 9 , the hypothesis of full short-run sterilization is given by:

(11) $\sum_{j=1}^{n} \beta_{1,3}=-1, \sum_{i=1}^{m} \gamma_{i, j}=-1$

The lower panel of table 3 reports the results of the tests for short-run sterilization. We test the hypothesis of full short-run sterilization separately for each type of intervention, and jointly. The hypothesis is not rejected for the total sample. Only for interventions in the EMS is full short-run sterilization rejected in the two 
Table 4

Results for Long-Run Sterilization (dependent variable $\Delta B$ )

\begin{tabular}{|c|c|c|c|c|c|c|c|c|c|c|}
\hline sriplote & & lags & & & & & $S E(\%)$ & r & A & \\
\hline & fe & $x_{8}$ & F & $s_{2}$ & r. & $x_{7}$ & & & & \\
\hline & $23+$ & 0.32 & 16 & 0.22 & 2.04 & 024 & 108 & 13.3 & 064 & \\
\hline & $54 \%$ & 0.66 & 16 & 0.74 & 19 & 0.66 & 165 & $63^{2}=$ & 0 & \\
\hline & 0.4 & 0.28 & 06 & -0.20 & 13 & 0.36 & 1. 4 4 & $1,8 \%$ & 984 & \\
\hline & 13 & -0.36 & 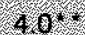 & 6.6 & 77 & 0.36 & 0.72 & $7,1=$ & 068 & \\
\hline
\end{tabular}

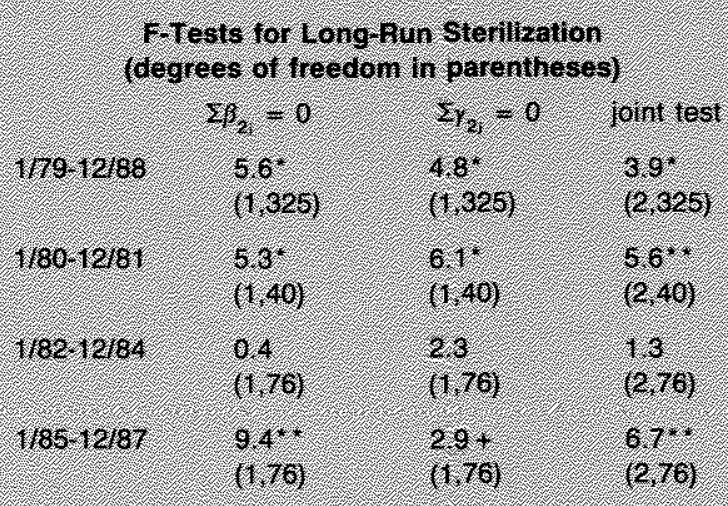

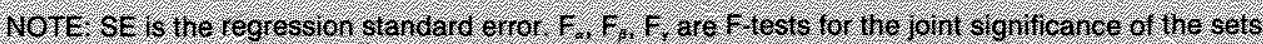

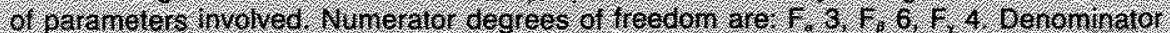

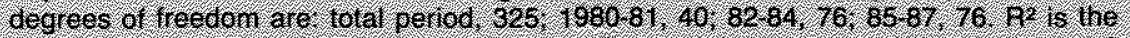

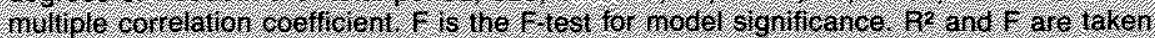
trom the secand stage estinates and apply to each equation ndvidually $A \mathrm{~F}(6)$ ts the

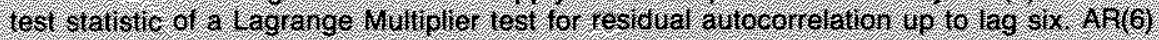

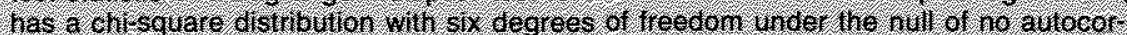

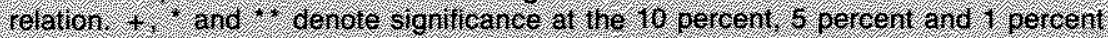
tevels:

subsamples with equal relative stances of the mark, 1980-81 and 1985-87. The hypothesis of full short-run sterilization of dollar market in. terventions is never rejected.

\section{Long}

Table 4 presents a similar summary of the results for the monetary base. Again, all regressions are found highly significant and without residual autocorrelation. When tested separate$\mathrm{y}$, the two sets of intervention variables enter these equations significantly only in the $1985-87$ subsample. However, if we test the significance of the dollar and the EMS interventions jointly, we find that the interventions fogether had significant consequences for German monetary base growth in 1980-81 and 1985-87. ${ }^{23}$ The sum of coefficients $\beta_{2, j}$ and $\gamma_{2, j}$ have the anticipated, positive signs in the total sample and these two subsamples.

The lower panel of this table reports the results of testing for full long-run sterilization:

(12) $\sum_{\mathrm{i}=1}^{\mathrm{N}} \beta_{2, \mathrm{j}}=0, \quad \sum_{j=1}^{\mathrm{M}} \gamma_{2, \mathrm{j}}=0$.

We reject full long-run sterilization for both types of interventions in the total sample and the two subsamples when the mark's move-

\footnotetext{
${ }^{29}$ The joint tests yield the following Fratios (degrees of freedom in parentheses): $1.5(10,325)$ for the total sample, $2.1^{*}(10,40)$ for $1980-81,1.3(10,76)$ for $1982-84$, and $4.8^{* *}(10,76)$ for $1985-87$
} 


\section{Estimates With Switching Parameters}

Table 4 indieates that the Bundeshank's long-run sterilization of foreign exchange interveritions varied substantially between The subperiods considered here But the estimates in these tables may suffer from small sample problems, as adeh subperiod is faily short to reduce this problent, I re estimate the systen using the total sample. 1979 io 1088, and modify the base equation to allow for regine shifts over tine: for this pinpose 1 define a dimmy variable with the value one for 1980,1981 . and 198516 1987, and zero elsewhere, and muliply it by the lagged nierrention vari. ables AIRS, and AME, The resulting Variables ane added as additional regressors to the base equations. The coetficients on these new regressors estimate the differ. ence between the impact of inieivemtions on monetary base growth in 1979, 19828 84 . and $1988 \mathrm{Vs}$. the remaining years:
The pestits of this step are reported in the table below. The first line of this table con. firms the significance of the new iegressors and lence, of the change in regression para: meters between the subperiods. Foreign ex. change market interventions had a sigmiticant longrun impact on base money growth in the years of 1980 10 1981 and 1985 to 1987. The second part of the table reports the esiinates $\Sigma \hat{\beta}_{2}$, and $\Sigma_{y_{2}}$ and 1 ie results of he tests for long-rim sterilization. Jong tur sterilitation prevailed in $1979,1982-84$ and 1988. However longrun stertluation is strongly rejected for the remaining vears: when the mart had simitar relative positions in the EMS and the dollar narket thus, the table corroburates the results of the carlier tables:

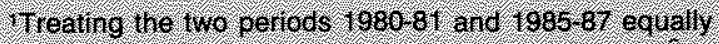
is justifed by the resuit n trable 4 that he sums 2 ? and 3 ,, in he base egualion are simiar $10.1 \mathrm{mese}$. perods a sinlar nodrcation for the transilory campo hent seens unirecessay, as we lind fill shortwh sterfization unionily lor all subpentods:

\section{Estimates of Base Equation with Shifting Parameters}

Dependent Varable, 4 , sample 1979 10 1988

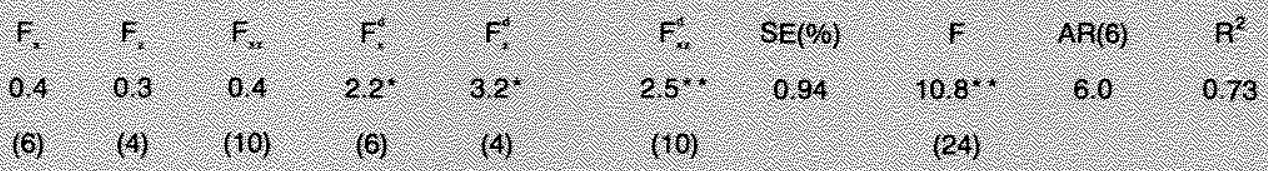

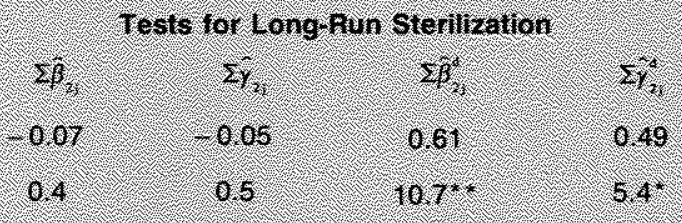

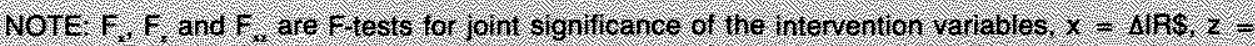
ARE Numbers in garentheses are nunetator degrees of 1 redon. Dehominator degrees.

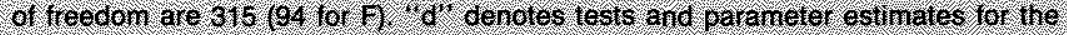

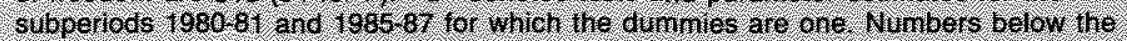
simpot-parameter estimates are Fvalues tor the null of tull long tun sterlization, with one numerator degree of treedon sog provious tables for wither symbols. 
ments against the dollar and the EMS were in the same direction. Thus, the impact of foreign exchange interventions on monetary base growth was significant in times when the two exchange rate constraints required intervention in the same direction. ${ }^{24}$

The empirical results for short-run and longrun sterilization are thus very different. In contrast to short-run sterilization, long-run sterilization, which is the more relevant issue for monetary policy, did not generally hold throughout the 1980s. The shaded insert on the opposite page illustrates how this important conclusion is missed if the analysis fails to recognize the Bundesbank's distinction between short-run and long-run sterilization.

\section{Do EMS Interventions and Dollar Interventions Have the Same Effects?}

Did the Bundesbank's sterilization procedures treat interventions in the EMS significantly different from interventions in the dollar market? To answer this question, we test the hypotheses:

(13) $\sum_{\mathrm{i}=1}^{\mathrm{N}} \beta_{1, j}=\sum_{j=1}^{\mathrm{m}} \gamma_{1, j}$ and $\sum_{j=1}^{\mathrm{N}} \beta_{2, j}=\sum_{j=1}^{\mathrm{M}} \gamma_{2, j}$

meaning that the extent of short- and long-run sterilization is the same for both types of interventions. The F-statistics pertaining to these tests for the total sample and the three subsamples are all well below the 10 percent significance levels. ${ }^{25}$ Thus, we do not reject the hypothesis that, apart from differences in timing, sterilization is the same on both markets.

Even though the extent of sterilization was the same in the dollar market and the EMS, dollar market and EMS intervention had different implications for monetary growth in Germany during the 1980s. This result is due to the

24Finding a significani impact of interventions on monetary base growth does not necessarily imply that interventions became an obstacle to monetary targeting. For example, if the Bundesbank wanted to hold a constant share of its total assets in international reserves, the latter would have to grow in line with the monetary base [e.g. Scholl (1983), p. 120 . In this case, such reversed causality between base growth and growth of international reserves could lead to similar regression results as those above. How. ever, we know from figure 1 that the net international reserves positions of the Bundesbank were subject to large swings, particularly during the years when long-run sterilization did not occur, which makes this interpretation implausible. marked differences in the time profiles of these interventions. EMS interventions have occurred on a large scale mostly around realignments of the central parities. As the realignments involved revaluations of the mark, the Bundesbank generally experienced large inflows of international reserves before realignments, due to interventions supporting weak currencies. But the new central parities were usually chosen such that the mark would be temporarily in a relatively weak position in the EMS after the realignment. The realignments triggered outflows of reserves, which offset the initial expansionary effect. ${ }^{26}$ This general pattern is clearly demonstrated in figure 1.

Similar, self-reverting tendencies did not, in general, occur for interventions in the dollar market. The long-lasting changes in dollar reserves shown in figure 1 suggest that interventions in the dollar market, especially in the two critical periods of $1980-81$ and 1985-87, had more permanent effects. These observations indicate that the monetary control implications of EMS and dollar market interventions have been very different: non-sterilized EMS interventions cause temporary deviations of monetary base growth from what is warranted by the monetary target. In contrast, dollar market interventions cause more permanent deviations and, particularly in the two critical periods, have contributed significantly to the over- and under-shooting of the monetary target. $^{27}$

\section{IMPLICATIONS FOR MONETARY POLICY}

The fact that the Bundesbank fully sterilizes foreign exchange interventions in the short run but does not generally do so in the long run can be interpreted in two ways. Incomplete long-run sterilization may reflect the lack of suf-

25The following F-values are computed for this test (degrees of freedom in parentheses). Equal short-run sterilization: $0.2(1,325), 2.8(1,40), 0.1(1,76), 2.2(1,76)$ for $1979-88$, 1980-81, 1982-84, 1985-87, respectively. Equal long-run steritization: $0.0(1,325), 0.0(1,40), 0.1(1,76)$, and 1.1 $(1,76)$. For the base equation with shifting parameters, the F-value for equal long-run sterilization is $0.2(1,315)$ for the interactive dummy terms.

${ }^{26}$ See Bundesbank, Monthly Report, November 1988, p. 34.

27This accords well with Dudler's (1988) assessment of the EMS and dollar market constraints. The result for the EMS also accords well with the findings about German dominance in the EMS in Fratianni and von Hagen (1990). 


\section{A Pitfall: Testing for Sterilization Using the Total Domestic Component}

The distinction between short and long-run sterilization, derived from the Bundesbanks: eperating principles, is crucial to assess the impaet of its exchange rate polictes on mone. lary control in Germany Ilad We looked cnly at the transitory component, we would have condinded that the Bakk fully sterized all in: terventions: this conchision, which has been reached by most studies of the bundestiank. would then suggest that exchange rate con: straints have not interfered win chemanys monetary targeting: The tests for long-rin sterilization, lowever show that this conclu: sion is erroneous.

Io funther demonstrite this point, I peplace the base equation in the regressions cited in the lext by an equation for the total domestic component, $\mathbf{M D}=\mathbf{M B}=\mathbf{M I}$. pollowing the procedire used in the prevens studies 1 allow for a rontemporaneous effect. And wo lags of the interventinn vartable. This vields the following estimates of $\sum \beta$, the totat in. pact of dollar market interventions: 1.06 for the total sample, 0.86 for $1980-81$, 1.64 for 1982-84, and - 1.25 for $1985-87$ I or the IMMS interventions, the total impact of interven. tions is estimated as $\Sigma_{2}=-1.02$ for the total sample. 1.11 tor 1980.81 , 0.99 for 1982.84 and 1.18 lor 1985.87 . In 110 ease do 1 reject the typotheses of complete sterilization. These resulits, similar 10 those for the transitory component, indicate that short-run Tluctuations in the total domestic component and its short-run co-novenents will the in tervention vaciable are dommated by changes in the transilory component. ficiently effective monetary control instruments, i.e., an institutional deficiency. Alternatively, incomplete long-run sterilization may reflect that, under certain circumstances, the Bundesbank is willing to give in on its monetary target and lend more weight to exchange rate considerations in its decisions. The Bank itself has argued repeatedly that the latter is true. ${ }^{28}$ Specifically, violations of the monetary target ranges have been justified ex post as necessary to reduce exchange rate pressures. From this perspective, the results tell us something about how the relative weights of exchange rate targets and the monetary target in the Bank's decisions vary over time: The monetary target dominates as long as the mark performs differently in the EMS than against the dollar, but the monetary target becomes subordinate if the mark is either strong or weak against both currency groups. ${ }^{29}$ The estimates in table 4 indicate that, under these circumstances, an intervention of, say, DM 1 billion, will raise the monetary base per- manently by DM 500 to 600 million over the next two quarters.

\section{The Effectiveness of "Sterilized" Intervention}

The empirical finding of a significant difference between short-run and long-run sterilization of foreign exchange interventions also sheds some light on how interventions affect exchange rates. Asset market theories of exchange rate determination hold that sterilized interventions have no exchange rate effect if market participants regard assets in the countries concerned as perfect substitutes. The reason is that such interventions do not effectively change the composition of private investors' portfolios, and, hence, cannot change relative asset prices. Leaving the two money supplies unaffected, such interventions merely exchange perfect substitutes. On this basis, the assertion of earlier studies that the Bundesbank perfectly sterilizes interventions in the dollar
2aSee Scholl (1983), p. 124, Dudler (1988), p. 74, Schlesinger (1988), p. 11, Bundesbank, Monthly Report, May 1988 , p. 20, and Rieke (1984), p. 53.
29Neumann (1984) concludes that the Bank raises the weight on the monetary target in response to increasing exchange rate uncertainty. 
market would imply that such interventions are ineffective, since the degree of capital mobility between Germany and the U.S. is high and it seems plausible to assume that short-term, interest bearing assets in the two countries are very close substitutes.

However, the Bundesbank does find sterilized interventions in the dollar market effective, and recent empirical research confirms its claim ${ }^{30}$. The distinction between perfect short-run and imperfect long-run sterilization becomes crucial in resolving this puzzle. If market participants understand that full sterilization holds only in the short run, while long-run sterilization is-or may be-incomplete, interventions would change market participants' expectations about the future growth of the money supply, and this change in expectations would lead to exchange rate movements even if the interventions were fully sterilized initially. That is, sterilized interventions act as a signal about future central bank behavior. This is the essence of Mussa's (1981) expectations argument of sterilized interventions. ${ }^{31}$ As Dominguez (1989) points out, market participants generally seern to be aware of central bank activities in the dollar market, so that they are able to read the intended signal. This lends some further plausibility to the expectations argument.

\section{The Bundesbark and the EMS}

The results provide some insights into the functioning of the EMS during the 1980s. They reject the popular hypothesis that sterilization of EMS interventions makes German monetary policy independent from policies in the EMS and puts the burden of adjustment to balance of payments problems on weak currency countries. ${ }^{32}$ The evidence suggests that the long-run independence of German money supply growth from influences in the EMS, shown in Fratianni and von Hagen (1990), should be rather attributed to the way realignments have been engineered in most cases. Our results suggest that, with its dual exchange rate constraint, the Bundesbank may be more likely to accept or even pressure for realignments to revaluate the strong mark in the EMS when the dollar is weak than when it is high, since the mark's strength in both markets reduces the scope for offsetting interventions. This may explain why realignments have indeed been preceded by periods of dollar weakness in most cases. ${ }^{33}$

\section{GONCLUSONS}

Our results can be summarized as follows: Over the entire period under consideration, I cannot reject the hypothesis that the Bundesbank sterilizes foreign exchange interventions completely in the short run. However, complete intervention sterilization does not generally occur in the long run. Foreign exchange market interventions affect German monetary base growth significantly when the mark's movements against the dollar and the EMS currencies are in the same direction, that is, when the mark is relatively strong or relatively weak in both markets at the same time. This was the case in five out of the 10 years from 1979 to 1988. In contrast, exchange rate policies have no significant effect on German monetary control when the mark has unequal relative positions on the two markets. This suggests that, generally, persistent net intervention affects monetary control.

The results indicate that the Bundesbank's dollar policies and participation in coordinated interventions since 1985 have contributed significantly to the excess growth of the German money supply, relative to the Bank's monetary targets in the second half of the 1980 s. The present revival of inflation in Germany-in the spring of 1989 , inflation in terms of the cost of living index was at an an" nual rate of 2.7 percent, up from zero in 1987 -marks one cost of this monetary overexpansion and, consequently, of the policies leading to it. This result suggests that international policy coordination schemes that focus on exchange rates are more costly than they were previously believed to be.
soDominguez (1989).

31Rieke (1984), p. 45, argues that the Bundesbank interprets the effectiveness of sterilized intervention on the basis of a signaling argument. The same argument from the Bank is reported by Funabashi $(1988)$, p. 34.
32Giavazzi and Giovamnini (1987), p. 253.

${ }^{3}$ Giavazzi and Giovarnini (1986). 


\section{PRERTERTCRS}

Bofinger, Peter. Das Europäische Währungssystem und die geldpolitische Koordination in Europa, Kredit und Kapital 21 (1988), p. 317-45.

Deutsche Bundesbank. Annual Reports 1979-1987, Frankfurt. Monthly Reports, various issues, Frankfurt. Geldpolitische Aufgaben und instrumente, Frankfurt (1985).

Camen, Ulrich. FRG Monetary Policy Under External ConStraints, 1979-84, Centre for European Policy Studies, Working Paper 21, Brusseis (1986).

Dominguez, Kathryn. Market Responses to Coordinated Central Bank Intervention, Working Paper, Carnegie-Rochester Conference on Public Policy (April 1989)

Dudler, Hermann Josef. "Monetary Pollcy and Exchange Market Management in Germany" in Bank for International Settlements, ed., Exchange Market intervention and Monetary Policy, (Basie, 1988).

Fratianni, Michele, and Jürgen von Hagen. "The EMS-Ten Years After," in Carnegie-Rochester Conference Series on Public Policy, vol. 32 (Amsterdam: North Holland, 1990).

Funabashi, Yoishi. Managing the Dollar: From the Plaza to the Louvre (Washington, D.C.: Institute for International Economics, 1988).

Giavazzi, Francesco, and Alberto Giovannini. "The EMS and the Dollar," Economic Policy 2 (1986), pp. 455-73.

"Models of the EMS: Is Europe a Greater Deutschmark Area?" in Rajph C. Bryant and Richard Portes, eds. Global Macroeconomics, (London: McMillan 1987).

Mastropasqua, C., S. Micossi and R. Rinaldi. "Interventions, Sterilization and Monetary Policy in the European Monetary System Countries, 1979-87," in F. Giavazzi, S. Micossi and M. Miller, eds., The European Monetary System (Cambridge University Press, 1988), pp. 252-87.
Mussa, Michael. The Role of Official intervention (Group of Thirty, 1981).

Neumann, Manfred J.M. "Intervention in the Mark/Dollar Market: The Authorities' Reaction Function," Journal of in. ternational Money and Finance 3 (1984), pp. 223-40. "Implementation of Monetary Policy in Gernany," Working Paper (University of Bonn, 1988).

Obstfeld, Maurice. "Exchange Rates, Inflation, and the Sterilization Problem: Germany, 1975-81," European Economic Review 21 (1983), pp. 161-89.

Rieke, Wolfgang, "Die Rolle von Interventionen als Bestimmungsfaktor der Wechselkurse beim 'Floating," " in Werner Ehrlicher and Rudolf Richter, eds., Devisenmarktinterventionen der Zentralbanken, (Berlin: Duncker and Humblot, 1984).

Roubini, Nouriel. "Sterilization Policies, Offsetting Capital Movements and Exchange Rate Intervention Policies in the EMS," chapter 4 of unpublished Ph.D. dissertation (Harvard University, 1988).

Schlesinger, Helmut. "Recent Experiences with Monetary Policy in the Federal Republic of Germany," in Karl Brunner and Manired J.M. Neumann, eds, Inflation, Unemployment and Monetary Control (Berlin: Duncker \& Humblot, 1979), pp. $303-20$

"The Setting of Monetary Objectives in Germany," in Paul Meek, ed., Central Bank Views on Monetary Targeting (Federal Reserve Bank of New York, 1983).

"Das Konzepi der Deutschen Bundesbank," in Werner Ehrlicher and Diethard B. Simmert, eds, Wandlungen des geldpolitischen Instrumentariums der Deutschen Bundesbank (Berlin: Duncker \& Humblot, 1988).

Scholl, Franz. "ilmplications of Monetary Targeting for Exchange Rate Policy," in Paul Meek, ed., Central Bank Views on Monefary Targeting (Federal Feserve Bank of New York, 1983).

von Hagen, Jürgen. "Alternative Operating Procedures for Money Stock Control in West Germany - An Empirical Evaluation;" Weltwirtschaftliches Archiv 124 (1988), pp. $89-109$ 